than are justified by the available results of experimental test, and favoured a five-band division of the spectrum for the control of energy distribution-one of the methods included in British Standard 1853 (1956).

Colour photography, with its possibilities for documentary and scientific record as well as for pictorial representation, was discussed as regards accuracy from both aspects : it is well known, however, that bearing in mind the inherent limitations of the process, its local colour accuracy is not to be reckoned in terms of discrimination limens. $\mathrm{Dr}$. R. W. G. Hunt presented a tentative theory of colour tolerance for pictorial similitude under varying conditions of adaptation which, subject to the validity of some doubtful assumptions, appeared to provide the basis for a theoretical criterion for the further refinement of the process.

\section{J. W. Perry}

2 MacAdam, D. L., J. Opt. Soc, Amer., 32, 247 (1942).

2 Priest, I. G., J. Opt. Soc. Amer., 16, 117 (1928).

${ }^{3}$ MacAdam, D. L., J. Opt. Soc. Amer., 33, 18 (1943).

'Brown, W. R. J., and MacAdam, D. L., J. Opt. Soc. Amer., 39, 454 (1949).

3 Judd, D. B., Amer. J. Physiol., 52, 418 (1939). See also Scofield, F., Judd, D, B., and Hunter, R. S., Bull. Amer. Soc. Test. Mat., (1942).

\title{
GENETIC ASPECT OF SOMATIC CELL VARIATION
}

W HILE our knowledge of variation within populations of micro-organisms is large and impressive, technical difficulties have impeded advance in the study of cell variation in somatic tissues. In consequence, our understanding of the basic feature in organic development and differentiation is scanty. It was therefore timely to choose the genetical aspects of somatic cell variation as the topic of discussion for the eleventh Biology Research Conference, held in Gatlinburg, Tennessee, during April 2-5, sponsored by the Biology Division of the Oak Ridge National Laboratory. About two hundred and fifty scientists attended.

The wide spectrum of somatic cell variations attributable to changes in the nuclear or cytoplasmic determinants of heredity was reviewed by C. Stern (Berkeley) and B. Ephrussi (Paris). In these detailed surveys, examples were given of various nuclear phenomena such as somatic crossing-over, rnutation, genome separation, chromosome elimination, nuclear fusion, and endomitosis which result in cellular variation. Ephrussi described particular changes occurring in cytoplasmic components, such as plastids and microsomes, and which can be studied by genetical methods.

Cells vary in their capacity to produce specific proteins which behave as antibodies. A. H. Coons (Boston) pointed out that cells not only acquire the ability to manufacture antibodies, but also retain this ability long after the antigenic stimulus has been removed. Coons provided evidence to show that these particular cells are stimulated to proliferate by a second exposure to antigen. The new cell population has the same immunological response. This phenomenon has all the characteristics of acquired inheritance of a cellular function. While Coons used immunological reagents tagged with fluorescent dyes to study antibody formation in vivo, J. Lederberg (Madison) and E. S. Lennox (Urbana) studied antibody production by single cells from hyperimmune animals in vitro, All these investigators failed to find evidence of production of more than one antibody by a single cell at any one time.

C. W. Cotterman (Dallas) analysed several cases of irregularity in the human ABO blood group in which a minute proportion of blood cells was of aberrant antigenic type. K. C. Atwood (Oak Ridge) described a method by which phenotype variability in human erythrocytes can be detected. Some of the variations discussed by these investigators may be explainable only by mutation, some may be serological freaks, others are no doubt only cases of homozygosis for one of a pair of heterozygous gene loci, brought about by loss, non-disjunction or somatic crossing. over of chromosomes. Though the exact mechanism by which Atwood's exceptional cells arise is yet to be determined, it seems reasonable to assume that in some instances mutation is the cause. Atwood estimates that the mutation-rate in the human erythrocyte is $3 \times 10^{-9}$ per hour or $7 \times 10^{-6}$ per cell division.

The antigenic properties of tumour cells have been studied by G. Klein (Stockholm). He induced tumours in $F_{2}$ hybrids of coisogenic resistant mice heterozygous for $H$-2 histocompatibility locus, and changes were detected in antigenicity when they were transplanted into the parental strains. The new tumour variants of Klein showed predilection for one of the parental strains, which raises the intriguing question : Does the missing complementary variant represent a reversion to normal cell behaviour ? J. Lederberg (Madison) in his summing-up of the Conference proposed the idea that Klein might be dealing with homozygosis for one of the two $H$-2 alleles in the heterozygote due to somatic crossing-over and that the closely linked and dominant gene for malignancy has been lost from one of the sister cells.

How specific interaction of genes may be the source of cellular variation was discussed by R. A. Brink (Madison). Analysing the behaviour of a mutable gene which determines pericarp colour in the endosperm of maize, he was able to disentangle some of the complexity of interaction between gene and its 'controllers' or 'modulators'. The latter are spatially associated with the gene and when they are transposed to new loci, phenotype differences are produced. Brink found no correlation of 'modulator' activity with orderly development, which suggests that they are not important determinants of differentiation. The possible path of interaction between factors, which results in the formation of the melanotic pseudo-tumours in Drosophila, was discussed by C. Barigozzi (Milan).

Impressive methodical refinements, both cytological and serological in nature, were employed by T. S. Hauschka (Buffalo) to demonstrate the wide spectrum of heterogeneity in tumour cell populations, and the various degrees of correlation which may exist between particular properties, for example, antigenic specificity, drug resistance and chromosome number. C. E. Ford (Harwell) carried out cytological analysis of spontaneous primary tumours in mice and those induced by radiation, and found that in some tumours the chromosome number was the same 
as in normal tissues, whereas in others the number varied but remained close to the normal diploid number. He provided evidence to suggest that the various chromosome types in tumours are very likely to have been derived through the operation of selection on existing variation. The extensive studies which have been carried out by Hauschka and his school have shown that during the development and 'progression' of tumours the numerical and structural changes in chromosomes can become determining factors of virulence, invasiveness and isoantigenicity. Their investigation can also be expected to throw light on some of the mechanisms which may be involved in the initial process of malignant transformation as well as in the differentiation of normal cells.

The usefulness of in vitro cultivation of mammalian cells in studying cell variations was stressed by $T$. T. Puck (Denver). His agar plating technique facilitates the maintenance of genetic stability in cell clones, and permits an investigation of the occurrence and behaviour of experimentally induced cell variants. Using his method, Marguerite Vogt (Pasadena) produced clones resistant to polio virus in a human epidermoid carcinoma (HeLa), cultivated in vitro. She found that the HeLa cell variants resistant to polio differ in morphology and chromosome numbers from the cells of sensitive clones. The mutation-rate of the resistant cell variants was estimated to be $8 \times 10^{-6}$. J. W. Braun (New Brunswick) discussed competitive interactions which occur in bacterial cell populations at metabolic level and argued that similar processes may be responsible for variations within somatic cell populations.

The observations of the various contributors demonstrated the great diversity of mechanism by which the cellular phenotype can be altered. Lederberg in his summary made an attempt to classify the molecular basis of information within the cell which determines the cellular phenotype. According to him, there are two kinds of information : 'nucleic' and 'epinucleic'; the former is determined by the base sequence of polynucleotides in the deoxyribonucleic acid molecule and it is constant from cell to cell. As 'epinucleic' phenomena, Lederberg suggested changes in the protein moiety or changes in the deoxyribonucleic acid structure not associated with base sequence alteration.

In order to distinguish between cell variants of different kinds, Lederberg stressed the importance of using normal, genetically labelled cells and of developing the new techniques which have already contributed much towards the understanding of the nature of somatic cell variation. P. C. KOLLER

\section{SOUTH-EASTERN UNION OF SCIENTIFIC SOCIETIES} HE South-Eastern Union of Scientific Societies
held its sixty-third Annual Congress in Reading
during April 9-12, under the presidency of Prof.
H. L. Hawkins. Throughout the Congress an
exhibition of biological, botanical and general interest
was on display in the Zoology Main Laboratory of
the University, including an exhibition of cold-water,
tropical and marine life shown by the Reading
Aquarists' Society. A young naturalists' evening was
held in the Chemistry Lecture Theatre and attracted
a large audience. Questions ranging over a large
number of subjects were answered by a panel of
experts. by Prof. H. L. Hawkins, who chose the title "All the World's a Stage". He began by pointing out that it is important to know something of the stage before considering the players. The stage is a chemical and physical one, never constant owing to imperfoction, but performances were as usual during alterations. Regarding the players, their exits were obvious, while they usually sneaked on unobserved. There were various parts to play, star and others. Players were always growing older, that is, changing, and the cast was continually renewed to replace the superannuated; with both the stage and players there was a limitation of scope. The newcomers were required to be adaptable-stereotyping of the performers could lead to their extinction and the change of scenery (environment) produced a change of type. There never was a real repetition. When men and women arrived there was the same stage with the same rules and, if the same sort of play, the same result. Humans were the only creatures able to have ideas beyond their experiences, having the capacity for modifying the stage, usually with disastrous results. The capacity for acting new plays is suggested but not yet adopted. The ability to have abstract thoughts should enable us to become humane animals, wherein is our only hope of survival.

The presidential address to the Archæological Section was given by Dr. M. Aylwin Cotton, who spoke on "Silchester Archæology". She said that during the past ten years remarkable progress had been made in the scientific techniques of archæological investigation. In briefly outlining the history of the exploration at Calleva Atrebatum which commenced in the sixteenth century, she mentioned the work of the Rev. J. G. Joyce (1864-78) and that of the Society of Antiquaries (1890-1909). Modern work, under her direction for the Ministry of Works and that of Mr. A. C. Boon for the Silchester Excavation Committee, had provided valuable chronological information. Recent methods for dating purposes included : tree ring counts, pollen analysis, fluorine and nitrogen tests and radiocarbon tests on organic material. The examination of crops on the ground was the earliest scientific technique (1744-45), it being recorded that observations on the colour and size of crops before harvesting revealed streets, the crops over them being stumpy through the lack of moisture. To-day, air photography, where suitable crops prevail, is most valuable in revealing buried features; this method, combined with the ground survey of the Ordnance Survey, provided the best working basis for the archæologist, especially in exploring the preRoman earthworks.

Measurement of electro-radioactivity was the latest method to be employed, the points of equal resistance being plotted on graphs to give contours. Dr. Cotton then mentioned the tests upon soil, soil formation, podsols and soil analysis for determining levels and the use of pottery and coins for dating, also the examination of plants and seeds which had revealed the existence of plants unrecorded since medieval times. Modern methods of preservation 